\title{
Chemicals profiling and antioxidants activities of Acacia seeds
}

\author{
Hédia Hannachi ${ }^{1}$, Walid Elfalleh ${ }^{1}$, Imen Ennajeh ${ }^{1}$, Mejda Laajel ${ }^{1}$, Mohamed-Larbi Khouja ${ }^{2}$, \\ Ali Ferchichi ${ }^{1}$ and Nizar Nasri ${ }^{3,4}$ \\ 'IRA, Laboratoire d'Aridoculture et cultures oasiennes. Médenine 4119, Tunisia. \\ ${ }^{2}$ Institut National de Recherches en Génie Rural Eaux et Forêts, P. B. 10, 2080 Ariana, Tunisia. \\ ${ }^{3}$ Laboratoire de Biochimie des Protéines et des Lipides, Campus Universitaire, Tunis 2092- Tunisia. \\ ${ }^{4}$ CSGA, UMR6265 CNRS, UMR1324 INRA, Université de Bourgogne, Agrosup Dijon, F-21000 Dijon, France.
}

Accepted 10 November, 2011

\begin{abstract}
This study reported investigations on phytochemical screening and antioxidants activities of seeds from seven Acacia species. Storage proteins and mineral contents were determined. The seed extracts of Acacia species were evaluated for their total phenols, flavonoids, carotenoids contents and total antioxidant capacity assessed by 2,2-azino-bis-3-ethylbenzothiazoline-6-sulfonic acid (ABTS) and 2,2diphenyl-1- picrylhydrazyl (DPPH) assays. Total protein content ranged from 99.49 (Acacia cyclops) to 142.77 (Acacia cyanaphylla) $\mathrm{mg} / \mathrm{g}$ dry weight basis (DW) according to the Acacia species, having an average of $120.41 \mathrm{mg} / \mathrm{g} \mathrm{DW}$. The albumin constitutes the major fraction presenting $31.11 \%$, followed by globulin (27.36\%), prolamin (22.27\%) and glutelin (19.27\%). The Acacia seeds were rich in minerals. The total phenolic compounds (TPC) determinate ranged from 154.47 (A. cyclops) to 1217.99 (Acacia horrida) with an average of $632.40 \mathrm{mg}$ gallic acid equivalents $/ 100 \mathrm{~g}$ DW. The total flavonoid contents have an average of $11.21 \mathrm{mg}$ rutin equivalents $/ 100 \mathrm{~g} \mathrm{DW}$, and the carotenoids mean is $4.23 \mathrm{mg} / \mathrm{kg}$. The Acacia seed extracts have an antioxidant activity reflected by the ABTS and DPPH tests. The Duncan's test showed significant difference of proteinic, phenolics, flavonoid and carotenoid contents according to the Acacia species. Therefore, natural components from Acacia seeds could be incorporated as food ingredient, without causing detrimental effects to the food's palatability and the functional ingredient's efficacy.
\end{abstract}

Key words: Acacia seeds, storage proteins, minerals, polyphenols, flavonoids, radical scavenging activity.

\section{INTRODUCTION}

Recently, there is a rising interest of natural antioxidants as currently used synthetic antioxidants have been suspected to cause or promote undesirable effects on human health. Research related to antioxidants represents nearly $70 \%$ of the studies used on functional foods today. Most of these studies involve natural ducts such as fruits, vegetables, whole grains, herbs and leaves. Plants are potential sources of natural antioxidants because they contain phenolic compounds such as

*Corresponding author. E-mail: hannachi_hedia @yahoo.fr. or walid.elfalleh@fst.rnu.tn. phenolic acids, flavonoids, tannins and phenolic diterpenes (Shahidi, 1997); some of them for example, tocopherols (vitamin E), ascorbic acid (vitamin C) and carotenoids are substances of major importance in human composition and food.

The large scale accessibility of agricultural and Industrial plant waste materials and their low cost makes them a striking source of natural antioxidants (Perez-Bonilla et al., 2006). Over the last years, researchers have become more and more interested in nutritional phenolic compounds because of their free radical scavenging activity and other potential beneficial effects on human health (Manach et al., 2004). Natural products based drugs have been used against various diseases since time 
Table 1. Seed morphological traits and data of Acacia species used in this study for chemicals profiling.

\begin{tabular}{lcccccc}
\hline Species & Latitude & Longitude & Length $(\mathbf{m m})$ & Width $(\mathbf{m m})$ & Weight 100 seeds $(\mathbf{g})$ & Color \\
\hline A. farnesiana & $33^{\circ} 53^{\prime} \mathrm{N}$ & $10^{\circ} 06^{\prime} \mathrm{E}$ & $9.827 \pm 3.454^{\mathrm{A}}$ & $5.212 \pm 0.428^{\mathrm{A}}$ & $8.181 \pm 2.597^{\mathrm{A}}$ & Brown $^{\mathrm{A}}$ \\
A. tortilis & $34^{\circ} 25^{\prime} \mathrm{N}$ & $08^{\circ} 47^{\prime} \mathrm{E}$ & $6.466 \pm 0.715^{\mathrm{A}}$ & $4.770 \pm 0.555^{\mathrm{B}}$ & $6.149 \pm 0.654^{\mathrm{B}}$ & Brown $^{\mathrm{A}}$ \\
A. mollissima & $35^{\circ} 17^{\prime} \mathrm{N}$ & $10^{\circ} 41^{\prime} \mathrm{E}$ & $4.254 \pm 0.397^{\mathrm{A}}$ & $2.898 \pm 0.536^{\mathrm{D}}$ & $1.428 \pm 0.121^{\mathrm{E}}$ & Black \\
A. cyanophylla & $34^{\circ} 42^{\prime} \mathrm{N}$ & $8^{\circ} 78^{\prime} \mathrm{E}$ & $9.313 \pm 1.75^{\mathrm{A}}$ & $2.438 \pm 0.290^{\mathrm{E}}$ & $1.732 \pm 0.711^{\mathrm{E}}$ & Dark brown \\
A. horrida & $36^{\circ} 36^{\prime} \mathrm{N}$ & $08^{\circ} 58^{\prime} \mathrm{E}$ & $5.527 \pm 0.796^{\mathrm{A}}$ & $3.938 \pm 0.290^{\mathrm{C}}$ & $3.342 \pm 0.213^{\mathrm{D}}$ & Greenish \\
A. salicina & $33^{\circ} 21^{\prime} \mathrm{N}$ & $10^{\circ} 30^{\prime} \mathrm{E}$ & $9.740 \pm 7.337^{\mathrm{A}}$ & $3.978 \pm 1.656^{\mathrm{C}}$ & $4.430 \pm 0.430^{\mathrm{C}}$ & Dark brown \\
A. cyclops & $33^{\circ} 44^{\prime} \mathrm{N}$ & $10^{\circ} 45^{\prime} \mathrm{E}$ & $5.127 \pm 0.357^{\mathrm{A}}$ & $4.552 \pm 0.780^{\mathrm{B}}$ & $4.579 \pm 1.859^{\mathrm{C}}$ & Dark brown \\
\hline
\end{tabular}

$\left.{ }^{*}\right)$ Each value in the table is represented as mean $\pm S D(n, 30) .\left(^{* \star}\right)$ Superscript letters with different letters in the same column of cultivar, respectively indicate significant difference $(p<0.05)$ analyzed by Duncan's multiple range test.

immemorial and are a significant part of today's drugs. Folk-lore used herbs as therapeutics and medicaments. The importance of some plants has long been published but a large number of them remain unknown yet. So, it is essential to explore their uses and to conduct pharmacognostics and pharmacological studies to discover their therapeutic uses.

Recently, many flavonoids have been isolated and identified from various plants, including fruits (Havsteen, 2002). In fact, the beneficial health effects of fruits are generally attributed to flavonoids. It has been found that these bioactive compounds possess a high effect to reduce several diseases such as cardiovascular, neurodegenerative and lung cancers (Ozgen et al., 2008; Shen et al., 2009). Since ancient times, several diseases have been treated by administration of plant extracts based on traditional medicine (Pezzoto, 1997). Investigation of traditionally used medicinal plants is thus, valuable on two levels; firstly, as a source of potential chemotherapeutic drugs, and secondly, as a measure of safety for the continued use of medicinal plants. In fact, plants and microorganisms provide the pharmaceutical industry with some of the most important sources of components for the research of new medications.

Research has increased to investigate new natural sources of antioxidants, especially from underexploited plants. The genus Acacia comprises approximately 1350 species (Maslin et al., 2003), widespread in the warm sub-arid and arid parts of the world. It has been reported that various Acacia species were rich in secondary metabolites such as alkaloids, cyanogenic glycosides, cyclitols, gums, terpenes, flavonoids and condensed tannins (Maslin et al., 2003). Acacia is used in traditional medicine as an antibacterian, antioxidant, antiinflammatory, astringent, antispasmodic and antiarythmic agent (El Abbouyi et al., 2004).

Despite the occurrence of some published preliminary work describing the phytochemical contents of the Acacia leaf in Tunisia (Bouhlel et al., 2007), little is known about the phytochemicals of Acacia seeds. Owing to the role of antioxidants in the indicated medicinal and nutritional uses of the plant, our present study was designed to isolate the antioxidant principles, proteins and their fraction constituents from seeds of seven Tunisian Acacia species. The antioxidant capacity of Acacia seed extracts were evaluated using radical scavenging activity of 2,2diphenyl-1- picrylhydrazyl (DPPH) and 2,2-azino-bis-3ethylbenzothiazoline-6-sulfonic acid (ABTS) tests.

\section{MATERIALS AND METHODS}

\section{Plant materials}

Seeds were randomly picked from at least three trees of each Acacia species. Samples from fully mature fruits were included in the present study. Acacia seeds came from seven species located in Tunisia. Thirty (30) seeds were sampled on each Acacia species. Three pomological parameters were determined; length, width and weight of 100 seeds. Each parameter value is represented as mean \pm standard deviation $(n, 30)$. The colors of Acacia seeds were also evaluated. Table 1 gives more information about their geographical origin and their seed pomology.

\section{Chemicals}

All solvents used were of reagent grade without any further purification. Gallic acid, rutin and Folin-Ciocalteu's phenol reagent were purchased from Sigma Chemical Co. (St. Louis, MO, USA). $\mathrm{DPPH}$ and ABTS were purchased from Sigma Chemical Co. (Poole, Dorset, UK). 6-hydroxy-2,5,7,8-tetramethylchroman-2carboxylic acid (Trolox) was obtained from Fluka Chemical Co. (Ronkonkoma, NY, USA). The analytical reagent grade methanol was obtained from Lab-Scan (Labscan Ltd, Dublin, Ireland). The water used in sampling was prepared with a Millipore Simplicity (Millipore S.A.S., Molsheim, France). Spectrophotometric measurements were performed on Shimadzu UV-1600 spectrometer (Shimadzu, Kyoto, Japan).

\section{Storage proteins extraction from Acacia seed}

In order to extract all classes of storage proteins of Acacia seeds, we adopted a fractionation protocol of the various categories of proteins based on their solubility differences as described previously by Nasri and Triki (2007) and later by Elfalleh et al. (2010). The extraction procedure is based on solubility differences of proteins in various solvents (Osborn, 1924). First, a milled sample (500 mg dry weight (DW) of delipided seed) was extracted with distilled water $(10 \mathrm{ml})$. The suspension was stirred at laboratory temperature for $20 \mathrm{~min}$ and then centrifuged at $10000 \mathrm{rpm}$ for $15 \mathrm{~min}$. The filtrated supernatant was used as the 
extract 1 (albumin fraction). The remaining insoluble sample was mixed with $10 \mathrm{ml}$ of aqueous $\mathrm{NaCl} 5 \%(\mathrm{w} / \mathrm{v})$ solution. The extraction procedure was repeated, and the extract 2 was collected (globulin fraction). After following extractions with aqueous $70 \%(\mathrm{v} / \mathrm{v})$ ethanol and aqueous $0.2 \% \mathrm{NaOH}$ solution, the extract 3 (prolamin fraction) and extract 4 (glutelin fraction) were obtained.

\section{Storage protein quantification using Bradford assay}

The protein content of each sample was quantified using method according to Bradford (1976). $100 \mathrm{mg}$ Coomassie Brilliant Blue G250 (Sigma-Adrich Co) was dissolved in $50 \mathrm{ml}$ ethanol (95\%) and $100 \mathrm{ml}$ of phosphoric acid (85\%) was added. The solution was diluted, filtered and used as the color reagent for protein quantification. Standard solutions of reagent grade BSA (EquitechBio, Inc., Kerriville, TX) were prepared containing 0 to $400 \mu \mathrm{g}$ proteins. Samples were covered with parafilm mixed and then incubated for $5 \mathrm{~min}$ before absorbance measurement at $595 \mathrm{~nm}$ in spectrophotometer (Anthelie Advanced, Microbeam, and S.A). All standard and unknown samples possessed the same solution matrix. The protein content of each sample was determined by fitting a least squares regression curve of the quantity of standard protein concentration versus photometric absorbance.

\section{Minerals contents}

Minerals were quantified in triplicate as previously described (Elfalleh et al., 2009). Plant material was dried at $70^{\circ} \mathrm{C}$. One gram $(1 \mathrm{~g})$ of powdered form of the sample was placed in a porcelain crucible in a muffle fumace at a temperature of $550^{\circ} \mathrm{C}$. After cooling, the ash was suspended in $5 \mathrm{ml}$ of deionised water and 1 $\mathrm{ml}$ of hydrochloric acid; and was autoclaved. The crucible contents were then filtered and diluted to $100 \mathrm{ml}$ with water. The resulting solution was used for mineral analysis. The combined concentration of calcium and magnesium ions was determined by complexometric titration (Ringbom et al., 1958). The sodium and potassium were determined by flame photometer (Sherwood 410, Sherwood Scientific Ltd, Cambridge, UK). Total phosphorus was determined by a spectrophotometer (Secomam S1000, Secomam, Ales and France).

\section{Carotenoid analysis}

The quantification of carotenoids as xanthophylls and carotenes entail with the determination of chlorophyll (Chl) Chla and Chlb by UV-VIS spectroscopy. Chlorophyll and carotenoids were extracted from Acacia seed using a method modified by Gitelson et al. (2003). Briefly, samples were put into a pre-chilled tube and ground for $3 \mathrm{~min}$ in $1 \mathrm{ml}$ extraction buffer $(80 \%$ acetone: Tris- $\mathrm{HCl}[1 \%$, $\mathrm{w} / \mathrm{v}])$. After the pigments were completely extracted by the buffer, an additional $1 \mathrm{ml}$ extraction buffer was used to wash the pestle. All extraction solutions were combined and debris was removed by centrifugation. A volume of $1 \mathrm{ml}$ of the supernatant was diluted to 3 $\mathrm{ml}$ final solution. The light absorbance of the final solution was measured at 663, 647 and $470 \mathrm{~nm}$. The concentrations of carotenoids and chlorophyll were calculated as described by Lichtenthaler (1987). All experiments were done in triplicate and the carotenoid contents were converted to $\mathrm{mg}$ per $\mathrm{kg}$ of fresh weight.

\section{Phenolics extraction}

Total phenolic compounds (TPC) were extracted from the seed powders. The seed powder $(10 \mathrm{~g})$ was extracted and stirred with
$100 \mathrm{ml} \mathrm{MeOH}$ at $30^{\circ} \mathrm{C}$ for one night. The extract was fi lteredthrough Whatman no. 1 filter paper for removal of seed particles. The residue was re-extracted with $60 \mathrm{ml}$ methanol. The obtained extracts were filtered again. Acacia seed extracts were pooled and concentrated under vacuum at $40^{\circ} \mathrm{C}$. Obtained methanol ic extract were used for phenolic and antioxidant analyses.

\section{Determination of total polyphenols and total flavonoids contents}

The Folin-Ciocalteu method was used to measure the TPCs (Elfalleh et al., 2009). For the analysis, from each sample, $0.5 \mathrm{ml}$ of methanolic extract solution was added to $0.5 \mathrm{ml}$ of Folin-Ciocalteu reagent (Prolabo, Paris France), followed by $4 \mathrm{ml}$ of $1 \mathrm{M}$ sodium carbonate. Next, the test tubes were incubated at $45^{\circ} \mathrm{C}$ for $5 \mathrm{~min}$ and then cooled in cold water. Absorbance was measured at 765 nm, using a Shimadzu 1600-UV spectrophotometer (Shimadzu, Kyoto, Japan). The results were compared to a gallic acid calibration curve, and the TPCs were determined as mg gallic acid equivalents per $100 \mathrm{~g}$ DW (GAE mg/100 g DW). Determination of each sample was performed in triplicate.

Total flavonoids were measured spectrophotometrically in triplicate following the method described previously (Elfalleh et al., 2009). This method is based on the formation of a complex flavonoid-aluminium, having the maximum absorbance at $430 \mathrm{~nm}$. Rutin was used to make a calibration curve. One $\mathrm{ml}(1 \mathrm{ml})$ of methanolic extract was mixed with $1 \mathrm{ml}$ of $2 \% \mathrm{AlCl}_{3}$ methanolic solution. After incubation at room temperature for $15 \mathrm{~min}$, the absorbance of the reaction mixture was measured at $430 \mathrm{~nm}$ using a Shimadzu 1600-UV spectrophotometer. The flavonoids content was expressed as rutin equivalents in $\mathrm{mg}$ per $100 \mathrm{~g} \mathrm{DW}$ (mg $\mathrm{RE} / 100 \mathrm{~g} \mathrm{DW}$ ).

\section{Antioxidant activities}

2,2-Diphenyl-1-picrylhydrazyl (DPPH) and 2,2-azino-bis-3-
ethylbenzothiazoline-6-sulfonic $\begin{aligned} & \text { acid } \\ & \text { scavenging activities }\end{aligned}$ (ABTS) radical

The scavenging activity of methanolic extracts on DPPH radical was determined in triplicate following the method reported by Okonogi et al., (2007). A methanolic test solution of defferent concentrations was prepared from a stock solution of seed extracts (1 mg of dry powder per ml). DPPH $(100 \mu \mathrm{M})$ was dissolved in ethanol and mixed with an aliquot of $100 \mu \mathrm{l}$ of each dilution. After the reaction was allowed to take place in the dark for $30 \mathrm{~min}$, then the absorbance at $517 \mathrm{~nm}$ was recorded to determine the concentration of remaining DPPH. Results were expressed as Trolox equivalent antioxidant capacity (TEAC).

The total antioxidant activity values were estimated in triplicate by TEAC. In this test, we measured the relative capacity of antioxidants to scavenge the $\mathrm{ABTS}^{+}$radical compared to the antioxidant potency of Trolox which is used as a standard. The ABTS $^{+}$radical was generated by mixing $7 \mathrm{mM}$ ABTS solution with $2.45 \mathrm{mM} \mathrm{K}_{2} \mathrm{~S}_{2} \mathrm{O}_{3}$ in the dark for $24 \mathrm{~h}$ at room temperature. Before usage, the $\mathrm{ABTS}^{+}$solution was diluted with ethanol to an absorbance of $0.700 \pm 0.020$ at $734 \mathrm{~nm}$ after $5 \mathrm{~min}$. $25 \mu \mathrm{l}$ of antioxidant sample or Trolox standard was added to $1 \mathrm{ml}$ of the diluted $\mathrm{ABTS}^{+}$solution. The reaction mixture was homogenised for $20 \mathrm{~s}$ and then the absorbance was recorded at $734 \mathrm{~nm}$ at $5 \mathrm{~min}$. The final TEAC value of the antioxidant compound was calculated by comparing $\mathrm{ABTS}^{+}$decolourisation with Trolox, which gives a useful indication of the antioxidant potential of the plant extracts. Measurement was performed in triplicate." to "All measurements were performed in triplicate. 
Table 2. Seed storage protein composition ( $\mathrm{mg} / \mathrm{g}$ of dry weight basis of delipided seed) of Acacia species studied.

\begin{tabular}{lccccc}
\hline Species & Albumin & Globulin & Prolamin & Glutelin & $\boldsymbol{\Sigma}$ SSP \\
\hline A. farnesiana & $37.62 \pm 1.05^{\mathrm{B}}$ & $21.72 \pm 1.76^{\mathrm{E}}$ & $28.74 \pm 1.71^{\mathrm{B}}$ & $22.11 \pm 0.15^{\mathrm{C}}$ & $110.19 \pm 1.00^{\mathrm{C}}$ \\
A. tortilis & $26.82 \pm 0.99^{\mathrm{D}}$ & $31.59 \pm 1.73^{\mathrm{C}}$ & $33.62 \pm 2.13^{\mathrm{A}}$ & $19.44 \pm 0.09^{\mathrm{D}}$ & $111.47 \pm 1.10^{\mathrm{C}}$ \\
A. mollissima & $53.40 \pm 1.97^{\mathrm{A}}$ & $16.56 \pm 0.99^{\mathrm{F}}$ & $28.05 \pm 0.50^{\mathrm{B}}$ & $25.38 \pm 2.00^{\mathrm{AB}}$ & $123.39 \pm 4.21^{\mathrm{B}}$ \\
A. cyanophylla & $33.78 \pm 2.94^{\mathrm{C}}$ & $55.71 \pm 1.99^{\mathrm{A}}$ & $29.40 \pm 1.94^{\mathrm{B}}$ & $23.88 \pm 1.00^{\mathrm{BC}}$ & $142.77 \pm 5.79^{\mathrm{A}}$ \\
A. horrida & $26.91 \pm 2.06^{\mathrm{D}}$ & $28.14 \pm 1.02^{\mathrm{D}}$ & $31.29 \pm 1.73^{\mathrm{AB}}$ & $26.58 \pm 0.93^{\mathrm{A}}$ & $112.92 \pm 2.17^{\mathrm{C}}$ \\
A. salicina & $54.06 \pm 2.00^{\mathrm{A}}$ & $40.08 \pm 2.02^{\mathrm{B}}$ & $29.09 \pm 0.81^{\mathrm{B}}$ & $19.44 \pm 0.09^{\mathrm{D}}$ & $142.67 \pm 2.79^{\mathrm{A}}$ \\
A. cyclops & $29.61 \pm 2.99^{\mathrm{D}}$ & $36.80 \pm 3.15^{\mathrm{B}}$ & $7.52 \pm 4.16^{\mathrm{C}}$ & $25.56 \pm 2.00^{\mathrm{AB}}$ & $99.49 \pm 1.23^{\mathrm{D}}$ \\
Mean & $37.46 \pm 11.76$ & $32.94 \pm 12.93$ & $26.82 \pm 8.72$ & $23.20 \pm 2.93$ & $120.41 \pm 16.75$ \\
Proteinic fraction (\%) & 31.11 & 27.36 & 22.27 & 19.27 & 12 \\
\hline
\end{tabular}

$\left.{ }^{*}\right)$ Each value in the table is represented as mean \pm SD $(n, 3) .\left(^{* \star}\right)$ Superscript letters with different letters in the same column of cultivar, respectively indicate significant difference $(p<0.05)$ analyzed by Duncan's multiple range test.

\section{Statistical and chemometric methods}

The results of compound contents were reported as mean values of three replicates (mean \pm standard deviation, $\mathrm{n}, 3$ ). Data were compared on the basis of standard deviation of the mean values. Differences between mean values were assessed based on a oneway analysis of variance with a post-hoc determination using Duncan's multiple range tests and using Statistical software (version 8). The level of significance was set at $P<0.05$.

\section{RESULTS AND DISCUSSION}

\section{Proteins content of Acacia seeds}

The contents of storage proteins extracted from Acacia seeds have an average of $120.41 \mathrm{mg} / \mathrm{g}$ DW basis of delipided seed (Table 2). The two Acacia species cyanophylla and silicia have the highest protein contents, respectively 142.77 and $142.67 \mathrm{mg} / \mathrm{g} \mathrm{DW}$; whereas, the Acacia cyclops has the lowest protein content (99.49 $\mathrm{mg} / \mathrm{g} \mathrm{DW})$. The albumin is the major fraction $(31.11 \%)$, followed by globulin (27.36\%), prolamin $(22.27 \%)$ and glutelin (19.27\%) fractions. The Duncan's test showed significant differences between protein fractions of Acacia species. Ash content ranged from 2.10 (Acacia farnesiana) to $6.00 \%$ (Acacia cyanophylla). The variation of ash content did not showed a significant difference between Acacia species (Table 3).

The seed storage proteins are important because they ensure feeding the germinating embryo which enables it to attain the autotrophy. They are also important for the human and animal nutrition providing more than the half of daily protein requirement (Cheftel et al., 1985). Most of the physiologically active proteins (enzymes) are found in the albumin or globulin groups. Nutritionally, the albumins and globulins have a very good amino acid balance. Globulins, prolamins and glutelins as storage reserves are not present systematically in the seeds of all plant species (Bewley and Black, 1983). In the present study, four fractions (albumine, globuline, prolamin and glutelin) constitute the Acacia seeds protein (Table 2).
The differences between Acacia species suggested that the genotype is the major factor influencing the protein fractions constituents which are in agreement with those for most legumes (Vasconcelos et al., 2010). However, it has been reported that protein fractions varied according to several factors as in vignera genus, the extracting method, the cultivars and also the genetic and environmental factors (Adsule et al., 1986). Proteins from Acacia seeds are relatively abundant (12\%), and should be investigated further. Storage chemicals from seeds of non-conventional plants should be explored. Proteins, for example, play significant roles in human health. Mainly in developing countries where the average protein intake is less than required, it is essential to find new sources of edible protein and other nutrients to overcome the population problem.

\section{Mineral contents of Acacia seeds}

The mineral content of Acacia seeds was expressed as $\mathrm{mg}$ per $100 \mathrm{~g}$ DW basis (Table 3). Potassium is the most abundant mineral in dry Acacia seeds with an average of $530.07 \mathrm{mg} / 100 \mathrm{~g} \mathrm{DW}$, followed by the calcium and magnesium levels having $195.28 \mathrm{mg} / 100 \mathrm{~g} \mathrm{DW}$. The mean of phosphorus and sodium contents were, respectively 36.34 and $10.84 \mathrm{mg} / 100 \mathrm{~g} \mathrm{DW}$ (Table 3 ).

Duncan's test showed significant differences on the mineral contents of Acacia species. It has been reported that variation on mineral content in the leguminous plants could be related to genetic origin, geographical source and the level of soil fertility (Apata and Ologhobo, 1994).

\section{Antioxidants contents of Acacia seeds}

The total phenolics levels have an average of $632.40 \mathrm{mg}$ $\mathrm{GAE} / 100 \mathrm{~g}$ DW (Table 4). It varied from 154.47 ( $A$. cyclops) to $1217.99 \mathrm{mg} \mathrm{GAE} / 100 \mathrm{~g} \mathrm{DW}$ (Acacia horrida). The total flavonoid contents ranged from 7.10 (Acacia tortilis) to $29.35 \mathrm{mg} \mathrm{GAE} / 100 \mathrm{~g} \mathrm{DW}$ (Acacia cyanophylla). 
Table 3. Mineral contents* (mg per $100 \mathrm{~g}$ dry weight basis) from seeds of Acacia species studied.

\begin{tabular}{lccccc}
\hline Species & Ash (\%) & Phosphorus & Potassium & Sodium & Calcium and Magnesium \\
\hline A. farnesiana & $2.10 \pm 0.42^{\mathrm{A}}$ & $21.97 \pm 1.41^{\mathrm{CD}}$ & $276.00 \pm 31.11^{\mathrm{EF}}$ & $4.05 \pm 1.41^{\mathrm{C}}$ & $135.56 \pm 21.21^{\mathrm{C}}$ \\
A. tortilis & $4.41 \pm 0.56^{\mathrm{A}}$ & $31.75 \pm 4.24^{\mathrm{C}}$ & $236.57 \pm 28.28^{\mathrm{F}}$ & $9.11 \pm 2.83^{\mathrm{BC}}$ & $508.88 \pm 141.42^{\mathrm{A}}$ \\
A. mollissima & $4.00 \pm 1.41^{\mathrm{A}}$ & $20.18 \pm 5.66^{\mathrm{D}}$ & $389.29 \pm 77.78^{\mathrm{DE}}$ & $12.14 \pm 2.83^{\mathrm{AB}}$ & $126.11 \pm 21.21^{\mathrm{C}}$ \\
A. cyanophylla & $6.00 \pm 1.41^{\mathrm{A}}$ & $84.76 \pm 0.78^{\mathrm{A}}$ & $492.86 \pm 28.28^{\mathrm{D}}$ & $11.13 \pm 1.41^{\mathrm{AB}}$ & $73.33 \pm 2.83^{\mathrm{D}}$ \\
A. horrida & $4.35 \pm 1.41^{\mathrm{A}}$ & $44.68 \pm 4.24^{\mathrm{B}}$ & $778.01 \pm 70.71^{\mathrm{B}}$ & $8.10 \pm 2.83^{\mathrm{BC}}$ & $151.17 \pm 3.54^{\mathrm{C}}$ \\
A. salicina & $4.40 \pm 2.83^{\mathrm{A}}$ & $25.31 \pm 4.24^{\mathrm{CD}}$ & $630.86 \pm 42.43^{\mathrm{C}}$ & $13.16 \pm 2.83^{\mathrm{AB}}$ & $250.83 \pm 0.78^{\mathrm{BC}}$ \\
A. cyclops & $4.80 \pm 1.41^{\mathrm{A}}$ & $25.71 \pm 4.95^{\mathrm{CD}}$ & $906.87 \pm 70.71^{\mathrm{A}}$ & $18.22 \pm 5.66^{\mathrm{A}}$ & $121.11 \pm 28.28^{\mathrm{C}}$ \\
Mean & $4.29 \pm 1.16$ & $36.34 \pm 22.87$ & $530.07 \pm 253.48$ & $10.84 \pm 4.44$ & $195.28 \pm 148.38$ \\
\hline
\end{tabular}

$\left({ }^{*}\right)$ Each value in the table is represented as mean $\left.\pm \mathrm{SD}(\mathrm{n}, 3) .{ }^{* *}\right)$ Superscript letters with different letters in the same column of cultivar, respectively indicate significant difference $(p<0.05)$ analyzed by Duncan's multiple range test.

Table 4. Phytochemical and antioxidant screening of seeds of Acacia species studied.

\begin{tabular}{lccccc}
\hline Species & $\begin{array}{c}\text { Total phenolics } \\
(\mathbf{m g ~ G A E} / \mathbf{1 0 0} \mathbf{~ g ~ D W})\end{array}$ & $\begin{array}{c}\text { Total flavonoids } \\
(\mathbf{m g ~ R E} / \mathbf{1 0 0} \mathbf{~ g ~ D W})\end{array}$ & $\begin{array}{c}\text { Carotenoids } \\
(\mathbf{m g} / \mathbf{k g})\end{array}$ & $\begin{array}{c}\text { DPPH } \\
\text { (TEAC mM) }\end{array}$ & $\begin{array}{c}\text { ABTS } \\
\text { (TEAC mM) }\end{array}$ \\
\hline A. farnesiana & $275.98 \pm 20.00^{\mathrm{E}}$ & $12.10 \pm 1.73^{\mathrm{BC}}$ & $1.20 \pm 0.18^{\mathrm{C}}$ & $0.78 \pm 0.06^{\mathrm{A}}$ & $2.45 \pm 0.20^{\mathrm{A}}$ \\
A. tortilis & $536.77 \pm 26.46^{\mathrm{D}}$ & $7.10 \pm 2.00^{\mathrm{D}}$ & $6.71 \pm 1.00^{\mathrm{A}}$ & $0.84 \pm 0.03^{\mathrm{A}}$ & $2.22 \pm 0.20^{\mathrm{A}}$ \\
A. mollissima & $718.91 \pm 81.15^{\mathrm{BC}}$ & $9.08 \pm 0.79^{\mathrm{CD}}$ & $3.28 \pm 0.49^{\mathrm{B}}$ & $0.84 \pm 0.10^{\mathrm{A}}$ & $0.90 \pm 0.09^{\mathrm{C}}$ \\
A. cyanophylla & $190.80 \pm 15.67^{\mathrm{E}}$ & $29.35 \pm 2.00^{\mathrm{A}}$ & $6.21 \pm 0.93^{\mathrm{A}}$ & $0.88 \pm 0.07^{\mathrm{A}}$ & $1.29 \pm 0.18^{\mathrm{B}}$ \\
A. horrida & $1217.99 \pm 200.00^{\mathrm{A}}$ & $12.84 \pm 2.27^{\mathrm{B}}$ & $4.23 \pm 0.63^{\mathrm{B}}$ & $0.34 \pm 0.03^{\mathrm{B}}$ & $2.25 \pm 0.20^{\mathrm{A}}$ \\
A. salicina & $650.92 \pm 40.00^{\mathrm{CD}}$ & $12.61 \pm 1.65^{\mathrm{B}}$ & $1.25 \pm 0.19^{\mathrm{C}}$ & $0.32 \pm 0.02^{\mathrm{B}}$ & $0.66 \pm 0.20^{\mathrm{C}}$ \\
A. cyclops & $154.47 \pm 32.95^{\mathrm{E}}$ & $11.39 \pm 2.08^{\mathrm{BC}}$ & $6.71 \pm 1.00^{\mathrm{A}}$ & $0.33 \pm 0.06^{\mathrm{B}}$ & $1.24 \pm 0.24^{\mathrm{B}}$ \\
Mean & $632.40 \pm 358.85$ & $11.21 \pm 2.29$ & $4.23 \pm 2.42$ & $0.62 \pm 0.27$ & $1.57 \pm 0.72$ \\
\hline
\end{tabular}

$\left.{ }^{*}\right)$ Each value in the table is represented as mean $\left.\pm S D(n, 3) .{ }^{* *}\right)$ Superscript letters with different letters in the same column of cultivar respectively indicate significant difference $(p<0.05)$ analyzed by Duncan's multiple range test.

Little information is available for antioxidants from Acacia seeds. As for Acacia salicina leaves, phenolic contents were ca.180 $\mu \mathrm{g} \mathrm{GAE} / \mathrm{g}$ DW (Chatti et al., 2009).

Phenolic compounds of more than 8000 known, embrace a wide range of plants secondary metabolites (Harborne, 1994; Pietta, 2000). Phenolic compounds are the most widely distributed secondary metabolites, ubiquitously present in the plant kingdom. Flavonoids constitute the largest class of phenolic compounds with more than 5000 structures, possessing in common a flavylium unit (C6-C3-C6) (lacobucci and Sweeny, 1983).

Phenolics play an important role in plant metabolism, but also protect the plant against stresses. For instance, it has been recently shown that flavonoids, such as catechin, regulate the auxin transport in plants, and therefore, play an important role in plant development (Brown et al., 2001). Several studies have shown that the plant resistance to both biotic (pathogens and predators) and abiotic (UV-radiation, drought, etc.) stresses is related to phenolic compounds (Parr and Bolwell, 2000; Dicko et al., 2005). All classes of phenolic compounds (hydroxybenzoic acids, hydroxycinnamic acid derivatives, flavonoids, polyflavans, etc.) are involved in the resistance mechanisms.
A number of highly reactive oxygen species such as singlet oxygen (1O2), superoxide anion radical (O2•-), hydroxyl radical $(\mathrm{OH} \bullet)$, nitric oxide radical $(\mathrm{NO} \bullet)$ and alkyl peroxyl (ROO•) are regularly produced in the human body (Langseth, 1995). These radicals can damage lipids, proteins and DNA and participate in pathogenesis and ageing (Ryan and Robards, 1998; Santos-Buelga and Scalbert, 2000; Parr and Bolwell, 2000). Phenolic compounds together with other natural compounds (vitamins $\mathrm{C}$ and $\mathrm{E}$, and carotenoids), contribute to the defense by scavenging free radicals, inhibiting oxidative enzymes such as lipooxygenase and cyclooxygenase and chelating metal ions (Shi et al., 2001).

The antioxidant activities of the extracts from Acacia seeds were evaluated as TEAC calculated from DPPH•and ABTS $\bullet+$ scavenging capacity (Table 4).

The free radical scavenging activity determined by DPPH varied from 0.32 (Acacia salicina) to $0.88 \mathrm{mM}$ TEAC (A. cyanophylla) with an average of $0.62 \mathrm{mM}$ TEAC in Acacia seeds extract. The values determined by ABTS ranged from 0.66 (A. salicina) to $2.45 \mathrm{mM}$ TEAC (Acacia farnesiana), with an average of $1.57 \mathrm{mM}$ TEAC.

Free radical scavenging activity determined by DPPH and ABTS were usually used in several plant extracts 
(Elfalleh et al., 2009; Nasri et al., 2011).

Considering that multiple reaction characteristics and mechanisms involved in the estimation of the total antioxidants, no single method could accurately reflect all the antioxidants in a mixed system due to the complex nature of phytochemicals (Chu et al., 2000). Currently, the ABTS method was used to confirm the results obtained on the DPPH test since both methods are based on a similar antioxidant mechanism and the extracts used in both tests were methanol-soluble.

The antioxidant activity of phenolic compounds is mainly due to their redox properties, which can play an important role in adsorbing and neutralizing free radicals (Bors et al., 2001). In addition, synergism between the antioxidants in the mixture makes the antioxidant capacity not only dependant on the concentration, but also on the structure and the interaction between the antioxidants (Djeridane et al., 2006).

Antioxidant activities of phenolic compounds have been suggested to exert beneficial pharmacological effects on neurological disorders on the basis of in vitro observations (Moosmann and Behl, 1999).

\section{Conclusion}

These results obtained show that the unexploited Acacia seeds seem to be a new interesting natural source of protein, minerals and antioxidants. The Acacia seed extracts showed antioxidant activities reflected by ABTS and DPPH tests. Therefore, consumption of food produced with natural compounds extracts (functional foods) is expected to prevent the risk of free radical dependent diseases. The use of investigated natural resources spices such as the unexploited Acacia seeds could be useful not only in food and cosmetics production but also as important functional food in the prevention and treatment of various human diseases. The development of a functional food is a long and complex process, which requires multidisciplinary approaches. Acacia seed used for functional foods and dietary supplements is still in the development stage requiring continuing research.

\section{ACKNOWLEDGEMENT}

Authors are grateful to L. Ben Yahia and N. Kbaier from The Arid Land Institute for technical support.

\section{REFERENCES}

Adsule RN, Kadam SS, Salunkhe DK (1986). Chemistry and technology of green gram (Vigna radiate L. Wilczek. Food Sci. Nutr., 25: 73-105.

Apata DF, Ologhobo AD (1994). Biochemical evaluation of some Nigerian legume seeds. Food Chem., 49: 333-338.

Bewley JD, Black M (1983). Physiology and Biochemistry of Seeds. Springer, Berlin, Germany.
Bors W, Michel C, Stettmaier K (2001). Structure-activity relationships governing antioxidant capacities of plant polyphenols. Methods Enzymol., 335: 166-181.

Bouhlel I, Ben Mansour H, Limem I, Ben Sghaier M, Mahmoud A, Ben Chibani J, Ghedira K, Chekir-Ghedira L (2007). Screening of antimutagenicity via antioxidant activity in different extracts from the leaves of Acacia salicina from the center of Tunisia. Environ. Toxicol. Pharmacol., 23: 56-63.

Bradford MM (1976). A Rapid and sensitive Method for the quantification of Microgram Quantities of Protein Utilizing the Principle of Protein - Dye Binding. Anal. Biochem., 72: 248 - 254.

Brown DE, Rashotte AM, Murphy AS, Normanly J, Tague BW, Peer WA, Taiz L, Muday GK (2001). Flavonoids act as negative regulators of auxin transport in vivo in Arabidopsis. Plant Physiol., 126: 524-535.

Chatti IB, Limem I, Boubaker J, Skandrani I, Kilani S, Bhouri W, Ben Sghaier M, Nefatti A, Ben Mansour H, Ghedira K, Chekir-Ghedira L (2009). Phytochemical antibacterial antiproliferative and antioxidant potentials and DNA damage-protecting activity of Acacia salicina extracts. J. Med. Food, 12: 675-683.

Cheftel JC, Cuq JL, Lorient D (1985). Protéines alimentaires, Tec \& Doc Lavoisier, Paris.

Chu YH, Chang CL, Hsu HF (2000). Flavonoid content of several vegetables and their antioxidant activity. J. Sci. Food Agric., 80: 561566.

Dicko MH, Gruppen H, Barro C, van Berkel WJH, Voragen AGJ (2005). Impact of phenolics and related enzymes in sorghum varieties for the resistance and susceptibility to biotic and abiotic stresses. J. Chem. Ecol., 31: 2671-2688.

Djeridane A, Yousfi M, Nadjemi B, Boutassouna D, Stocker P, Vidal N (2006). Antioxidant activity of some Algerian medicinal plants extracts containing phenolic compounds. Food Chem., 97: 654-660.

El Abbouyi A, Toumi M, El Hachimi Y, Jossang A (2004). In vitro effects of aqueous seeds extract of Acacia cyanophylla on the opsonized zymosaninduced superoxide anions production by rat polymorphonuclear leukocytes. J. Ethnopharmacol.. 91: 159-165.

Elfalleh W, Nasri N, Marzougui N, Thabti I, M'Rabet I, Yahia Y, Lachiheb B, Guasmi F, Ferchichi A (2009). Physico-chemical properties and DPPH-ABTS scavenging activity of some local pomegranate (Punica granatum) ecotypes. Int. J. Food Sci. Nutr., 60: 197-210.

Elfalleh W, Nasri N, Sarrai N, Gasmi F, Marzougui N, Ferchichi A (2010). Storage proteins contents and morphological characters of some Tunisian pomegranate (Punica granatum L.) cultivars. Acta Bot. Gallic, 157: 401-409.

Harborne JB (1994). Do natural plant phenols play a role in ecology? Acta Hort., 381: 36-45.

Havsteen BH (2002). The biochemistry and medical significance of the flavonoids. Pharmacol. Ther., 96: 67-202.

lacobucci GA, Sweeny JG (1983). The chemistry of anthocyanins, anthocyanidins and related flavylium salts. Tetrahedron, 39: 30053038.

Langseth L (1995). Oxidants, antioxidants, and disease prevention. Bracco U (eds), ILSI Press, Belgium.

Lichtenthaler HK (1987). Chlorophyll florescence signature of leave the autumnal chlorophyll breakdown. J. Plant Physiol., 131: 101-110.

Manach C, Scalbert A, Morand C, Jimenez L (2004). Polyphenols: Food sources and bioavailability. Am. J. Clin. Nutr., 79: 727-747.

Maslin BR, Miller JT, Seigler DS (2003). Overview of the generic status of Acacia (Leguminosae: Mimosoideae). Austr. System. Bot., 16: 118.

Moosmann B, Behl C (1999). The antioxidant neuroprotective effects of estrogens and phenolic compounds are independent from their estrogenic. Proc. Natl. Acad. Sci., 96: 8867-8872.

Nasri N, Tlili N, Elfallah W, Cherif E, Ferchichi A, Khaldi A, Triki S (2011). Chemical Compounds from Phoenician Juniper Berries (Juniperus phoenicea). Nat. Prod. Res., 25(18): 1733-17742.

Nasri N, Triki S (2007). Les protéines de réserve du pin pignon (Pinus pinea L). C. R. Biologies, 330: 402-409.

Okonogi S, Duangrat C, Anuchpreeda S, Tachakittirungrod S, Chowwanapoonpohn S (2007). Comparison of antioxidant capacities and cytotoxicities of certain fruit peels. Food Chem., 103: 839-846.

Ozgen M, Durgac C, Serce S, Kaya C (2008). Chemical and antioxidant 
properties of pomegranate cultivars grown in the Mediterranean region of Turkey. Food Chem., 111: 703-706.

Parr AJ, Bolwell GP (2000). Phenols in the plant and in man. The potential for possible nutritional enhancement of the diet by modifying the phenols content or profile. J. Sci. Food Agric., 80: 985-1012.

Perez-Bonilla M, Salido S, Beek TA, Linares-Palomio PJ, Altarejos J, Nogueras $M(2006)$. Isolation and identification of radical scavengers in olive tree (Olea europaea) wood. J. Chromatogr. A, 1112: 311-318.

Pezzoto JM (1997). Plant derived anticancer agents. Biochem. Pharmacol., 2: 121-133.

Pietta PG (2000). Flavonoids as antioxidants. J. Nat. Prod., 63: 10351042.

Ringbom A, Pensar G, Wanninen E (1958). A complexometric titration method for determining calcium in the presence of magnesium, Anal. Chim. Acta, 19: 525-531.

Ryan D, Robards K (1998). Phenolic compounds in olives. Analyst., 123: 31-44.

Santos-Buelga C, Scalbert A (2000). Proanthocyanidins and tannin-like compounds: nature, occurrence, dietary intake and effects on nutrition and health. J. Sci. Food Agric., 80: 1094-1117.
Shahidi F (1997). Natural antioxidant: An overview. In: Shahidi F (eds) Natural Antioxidants, Chemistry, Health Effects and Applications, AOCS Press, New York, pp. 1-11.

Shen Y, Jin L, Xiao P, Lu Y, Bao J (2009). Total phenolics, flavonoids, antioxidant capacity in rice grain and their relations to grain color, size and weight. J. Cereal Sci., 49: 106-111.

Shi H, Noguchi N, Niki E (2001). Flavonoids and other polyphenols. Methods Enzymol., 335: 157-166.

Vasconcelos IM, Machado Maia FM, Farias DF, Campello CC, Urano Carvalho AF, Moreira R de A, Oliveira JTA (2010). Protein fractions, amino acid composition and antinutritional constituents of highyielding cowpea cultivars. J. Food Comp. Anal., 23: 54-60. 